\title{
Dynamics of dimethylsulfide production from dissolved dimethylsulfoniopropionate in the Labrador Sea
}

\author{
Sabine Schultes ${ }^{1,2}$, Maurice Levasseur ${ }^{1, *}$, Sonia Michaud ${ }^{1}$, Guy Cantin ${ }^{1}$, \\ Gordon Wolfe ${ }^{1}$, Michel Gosselin ${ }^{2}$, Stephen de Mora ${ }^{2}$ \\ ${ }^{1}$ Institut Maurice-Lamontagne, Ministère des Pêches et des Océans, C.P. 1000, Mont-Joli, Québec G5H 3Z4, Canada \\ ${ }^{2}$ Département d'océanographie, Université du Québec à Rimouski, 310 Allée des Ursulines, Rimouski, Québec G5L 3A1, Canada
}

\begin{abstract}
The dynamics of the cleavage of dissolved dimethylsulfoniopropionate $\left(\mathrm{DMSP}_{\mathrm{d}}\right)$ to dimethylsulfide (DMS) were measured experimentally in the surface waters of the Labrador Sea in spring 1997. At in situ $\mathrm{DMSP}_{\mathrm{d}}$ concentrations, DMS production and consumption processes were generally in balance. Two stations in the central Labrador Sea displayed net DMS production of approximately $2 \mathrm{nmol} \mathrm{l}^{-1} \mathrm{~h}^{-1}$, DMSP $\mathrm{d}$ net consumption of $3.48 \mathrm{nmol} \mathrm{l}^{-1} \mathrm{~h}^{-1}$ and a net DMS production yield from $\mathrm{DMSP}_{\mathrm{d}}$ of $60 \%$ at near in situ $\mathrm{DMSP}_{\mathrm{d}}$ concentrations. Similar to general bacterial substrate utilization in cold waters, DMS production in the Labrador Sea seemed to be temperature and substrate limited. Following DMSP ${ }_{d}$ additions, linear and non-linear net DMS production were observed. The non-linear response was characterized by a lag in DMS production and was associated with the cold, polar waters of the Labrador and West Greenland Currents. Net DMS production rates measured after $\mathrm{DMSP}_{\mathrm{d}}$ addition were proportional to the added amount of $\mathrm{DMSP}_{\mathrm{d}}$. No saturation of the net DMS production rate was observed for concentrations up to $5000 \mathrm{nmol} \mathrm{DMSP} \mathrm{d}_{\mathrm{d}} \mathrm{l}^{-1}$. First order rate constants determined for these DMS production kinetics suggest an average turnover time of DMSP $_{d}$ by cleavage to DMS of $3.8 \mathrm{~d}\left(2.7\right.$ to $5.2 \mathrm{~d}$ ). At water temperatures of -1.3 to $8^{\circ} \mathrm{C}$, potential net DMS production rates measured following $\mathrm{DMSP}_{\mathrm{d}}$ additions were comparable and even higher than those previously published for temperate and warm oceanic and coastal regions. The net DMS production

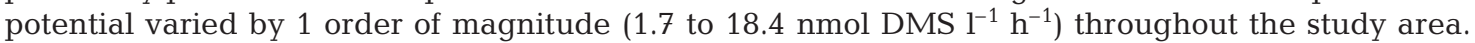
Causal links established with path analysis indicate that this potential seemed to be controlled by water temperature and chlorophyll a concentrations.
\end{abstract}

KEY WORDS: Dimethylsulfide (DMS) • Dimethylsulfoniopropionate (DMSP) · Production rates $\cdot$ Low temperature $\cdot$ Bacteria $\cdot$ Substrate utilization

\section{INTRODUCTION}

Dimethylsulfide (DMS, $\mathrm{CH}_{3} \mathrm{SCH}_{3}$ ) is the major volatile sulfur compound produced biogenically in the marine environment and has a global average concentration in oceanic surface waters of 1.2 to $3.8 \mathrm{nmol} \mathrm{l}^{-1}$ (Andreae 1990, Andreae \& Crutzen 1997). The concentration difference at the water-air interface is high enough to maintain a net flux of this compound to the atmosphere. The DMS emitted from the oceans is rapidly photooxidized to sulfur dioxide, methane sulfonic acid

${ }^{*}$ Corresponding author. E-mail: levasseurm@dfo-mpo.gc.ca
(MSA) and sulfate aerosols, that directly influence the Earth's radiation budget by backscattering a part of the incoming solar radiation. The aerosols also serve as cloud condensation nuclei (CCN) and thereby increase the Earth's albedo (Bates et al. 1987, Andreae et al. 1995, Malin 1996 and references therein). A hypothesis identifying marine DMS production as a biological climate regulation mechanism has been forwarded. According to Charlson et al. (1987), a rise in temperature due to global warming could enhance marine DMS emissions and in part counteract the greenhouse effect. Oceanic production and emission of DMS also play an important role in the biogeochemical cycle 
of sulfur (Lovelock et al. 1972, Andreae 1990, Bates et al. 1992).

The main precursor of DMS is dimethylsulfoniopropionate (DMSP, $\left[\mathrm{CH}_{3}\right]_{2} \mathrm{~S}^{+} \mathrm{CH}_{2} \mathrm{CH}_{2} \mathrm{COO}^{-}$), an osmolyte produced by certain groups of macro- and microalgae, similar in structure to the betaines (Vairavamurthy et al. 1985, Blunden \& Gordon 1986, see Kirst 1996 and Malin \& Kirst 1997 for a review). Among phytoplankton, dinoflagellates and prymnesiophytes are known to possess high intracellular DMSP (Keller et al. 1989). Release of DMSP into the water during the exponential growth phase of the algae, i.e. exudation, is considered to be small (Laroche et al. 1999). The formation of an important pool of dissolved DMSP $\left(\mathrm{DMSP}_{\mathrm{d}}\right)$ in marine surface waters is associated with cell senescence at the end of a bloom (Turner et al. 1988, Matrai \& Keller 1993, 1994, Levasseur et al. 1996) especially since autolysis of phytoplankton seems to be an important process in the natural environment (Van Boekel et al. 1992, Brussaard et al. 1995). Liberation of $\mathrm{DMSP}_{d}$ can furthermore be concomitant with DMS production via cell lysis due to zooplankton grazing (Dacey \& Wakeham 1986, Leck et al. 1990, Cantin et al. 1996, Levasseur et al. 1996) and viral infections (Malin et al. 1994, 1998, Bratbak et al. 1995, Hill et al. 1998). In open ocean regions, $\mathrm{DMSP}_{\mathrm{d}}$ concentrations as high as $200 \mathrm{nmol} \mathrm{l}^{-1}$ have been observed (Malin et al. 1993).

In the water column, $\mathrm{DMSP}_{\mathrm{d}}$ is subject to rapid turnover. A part of the $\mathrm{DMSP}_{\mathrm{d}}$ undergoes enzymatic cleavage forming DMS and acrylic acid in equimolar amounts (Challenger \& Simpson 1948, Cantoni \& Anderson 1956). Activity of the enzymes (DMSPlyases) catalyzing the cleavage of DMSP has been observed and characterized in certain algae, for example Phaeocystis sp. or Emiliania huxleyi (Stefels \& van Boekel 1993, Stefels \& Dijkhuizen 1996, Steinke et al. 1998), and in bacteria from various aquatic environments (de Souza \& Yoch 1995a, Taylor \& Visscher 1996 and references therein). Bacterial cleavage of DMSP to DMS and acrylic acid seems to be motivated by the use of the latter as a carbon source (Dacey \& Blough 1987, Ledyard 1993). By incubating whole surface water communities with additions of $\mathrm{DMSP}_{\mathrm{d}}$, it has been shown that enzymatic conversion of $\mathrm{DMSP}_{\mathrm{d}}$ to DMS is concentration and temperature dependent (Kiene \& Service 1991), and follows Michaelis Menten type kinetics (Ledyard 1993). In natural waters, the kinetic parameters $K_{\mathrm{m}}$ and $V_{\max }$ of $\mathrm{DMSP}_{\mathrm{d}}$ consumption and DMS production show as yet unexplained variability that could be due to differences in microbial communities on seasonal or spatial scales (Ledyard 1993, Ledyard \& Dacey 1996a,b).

Bacterial demethylation of $\mathrm{DMSP}_{\mathrm{d}}$ to 3-methylmercaptopropionate (MMPA) occurs concurrently with enzymatic cleavage and does not yield DMS (Kiene \&
Taylor 1988, Taylor \& Gilchrist 1991, Kiene 1996). The relative importance of demethylation and cleavage varies both temporally and spatially. Enzymatic cleavage can account for 0 to $100 \%$ of the $\mathrm{DMSP}_{\mathrm{d}}$ degraded in the natural environment (Kiene \& Service 1991, Ledyard \& Dacey 1996a) and the percentage has been suggested to change seasonally (Ledyard 1993). The factors that influence the amount of $\mathrm{DMSP}_{\mathrm{d}}$ converted to DMS are still not known. The kinetic parameters of both processes, $\mathrm{DMSP}_{\mathrm{d}}$ cleavage and demethylation, need to be measured in order to determine which process is dominant at a given ambient $\mathrm{DMSP}_{\mathrm{d}}$ concentration.

The bacterial community also consumes DMS (Kiene \& Bates 1990, Kiene \& Service 1991, Kiene 1992, Simó et al. 1995) thus playing a double role in $\mathrm{DMSP}_{\mathrm{d}} /$ DMS dynamics. Bacterial oxidation (Taylor \& Kiene 1989) and photooxidation of DMS (Brimblecombe \& Shooter 1986) lead to the formation of dimethylsulfoxide (DMSO). In return, DMSO can again be reduced to DMS by marine bacteria (Zinder \& Brock 1978, Jonkers et al. 1996). The sulfur species DMSO has recently gained rising attention due to improved analytical methods for its determination. New results indicate that DMSO in aquatic environments can act as a significant source of DMS rather than as a sink (de Mora et al. 1996, Simó et al. 1999). Another important DMS sink is its ventilation to the atmosphere (Bates et al. 1994, Liss et al. 1997), however, biological turnover of DMS is thought to be the dominating process in determining DMS concentration in marine surface waters (Kiene \& Bates 1990, Kiene \& Service 1991, Kiene 1992, Wolfe \& Bates 1993, Bates et al. 1994). It is still not known what controls bacterial DMS production and consumption, and thus the balance between the 2 processes.

It is obvious that variations in the balance between DMS production and consumption processes can significantly alter the amount of DMS emitted to the atmosphere. The kinetics of these processes seem to play a major role in determining DMS concentration in oceanic surface waters. The objective of this study was to measure DMS production from $\mathrm{DMSP}_{\mathrm{d}}$ in the Labrador Sea and to determine the kinetic parameters $K_{\mathrm{m}}$ and $V_{\max }$ of this process for whole communities from surface waters. We present the first data set showing the effect of $\mathrm{DMSP}_{\mathrm{d}}$ additions on DMS production in natural waters of temperatures ranging from -1.8 to $8^{\circ} \mathrm{C}$ and discuss spatial variations in potential net DMS production that were observed between the different water masses of the Labrador Sea in spring 1997.

\section{MATERIALS AND METHODS}

Sampling. During the scientific cruise NODEM I (Northern Oceans DMS Emissions Model) from 9 May 
to 12 June 1997, water from the upper water column ( 3 to $10 \mathrm{~m}$ ) was sampled at 16 stations located in the Labrador Basin, Labrador Current, West Greenland Current, North Atlantic Drift and on the NE Newfoundland Shelf (Fig. 1). Water was collected in 101 Niskin bottles and vertical profiles of temperature, salinity and fluorescence were obtained at all stations using a CTD (SeaBird 9/11 plus) mounted on a rosette sampler.

Subsamples of $500 \mathrm{ml}$ were filtered using Whatman $25 \mathrm{~mm} \mathrm{GF/F}$ filters and extracted with $90 \%$ acetone for $24 \mathrm{~h}$ at $4{ }^{\circ} \mathrm{C}$ for the subsequent determination of chlorophyll a ( $\mathrm{chl}$ a) using the fluorometric method of Yentsch \& Menzel (1963) as modified by Holm-Hansen et al. (1965). Samples were always extracted immediately and triplicates were done once a day to quantify the precision of the method (coefficient of variation $=7 \%$ ). For later determination of nutrients $\left(\mathrm{NO}_{3}{ }^{-}\right.$and $\left.\mathrm{NO}_{2}{ }^{-}\right)$ using a Technicon Autoanalyzer ${ }^{\circledR}$ (Strickland \& Parsons 1972), $20 \mathrm{ml}$ subsamples were filtered through a $25 \mathrm{~mm}$ GF/F filter and the filtrate was immediately frozen at $-80^{\circ} \mathrm{C}$. Subsamples of $250 \mathrm{ml}$ were fixed with $1.5 \mathrm{ml}$ acidic Lugol's solution for later identification and counting of phytoplankton cells using the Utermöhl technique (magnification of $250 \times$ or $400 \times$, Lund et al. 1958). A sample for the determination of bacterial abundance was collected and fixed with formaldehyde to giving final concentration of $3 \% \mathrm{v} / \mathrm{v}$. Cells were stained with 4 '6diamidino-2-phenylindole (DAPI, $5 \mu \mathrm{g} \mathrm{ml}^{-1}$ final concentration) and counted by epifluorescence microscopy (Porter \& Feig 1980, Velji \& Albright 1993).

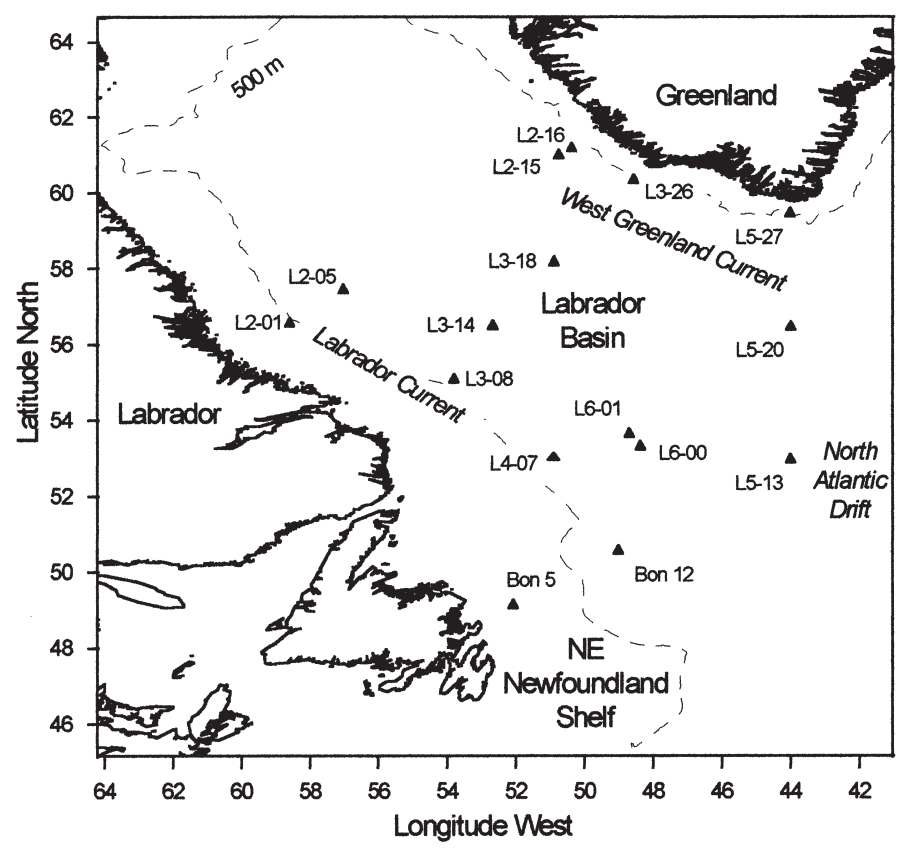

Fig. 1. Stations sampled for incubation experiments during NODEM 1 in the Labrador Sea
Incubation experiments. Water from 2 Niskin bottles closed at the same depth was mixed in equal amounts in an acid washed carboy. To remove large grazers, the water was pre-screened through a $202 \mu \mathrm{m}$ mesh. With exception of Stn L5-27, water was not pre-screened when Phaeocystis pouchetii was present to avoid removal of colonies. Phytoplankton cell counts were made from the same water as was used for the incubation. Being careful to minimize loss of DMS during handling, the water was gently poured into $250 \mathrm{ml}$ brown, high density polyethylene (HDPE) incubation bottles that had been soaked overnight in $10 \% \mathrm{HCl}$, then in deionized water and finally rinsed twice with the seawater used for the incubation.

A sterile stock solution of dissolved DMSP $\left(\mathrm{DMSP}_{\mathrm{d}}\right)$ was prepared by dissolving a weighed amount of DMSP-HCl (Research Plus Inc.) in deionized, autoclaved water. The stock solution was stored at $-20^{\circ} \mathrm{C}$ and for each incubation a new stock solution was taken in order to avoid cross-contamination and degradation of the stock during the cruise. Following the incubation protocol of Ledyard (1993), bottles were amended with $\mathrm{DMSP}_{\mathrm{d}}$. Additions ranged from 10 to $5000 \mathrm{nmol}$ $\mathrm{DMSP}_{\mathrm{d}} \mathrm{l}^{-1}$. For the kinetics experiments, the most frequent series of amendments was 50, 100, 500, 1000, 2000 and 3000 nmol DMSP $\mathrm{l}^{-1}$ (Stns Bon 12, L2-01, L2-16, L3-08, L3-14, L3-18, L3-26, L5-20, L5-27). The very first incubation of the series, at Bon 5, used lower additions $\left(10,20,50,100,500\right.$ and $\left.1000 \mathrm{nmol} \mathrm{l}^{-1}\right)$ and at Stn L5-13, additions as high as $5000 \mathrm{nmol} \mathrm{l}^{-1}$ were used, since no saturation was observed with $3000 \mathrm{nmol} \mathrm{l}^{-1}$ at the previous station (Bon 12). At Stns L2-05, L2-15, L2-16, L6-00, L6-01 and L4-07, DMS production from DMSP was measured following only 1 or 2 different $\mathrm{DMSP}_{\mathrm{d}}\left(500\right.$ and/or $2000 \mathrm{nmol} \mathrm{DMSP} \mathrm{l}^{-1}$ ) treatments. In all experiments, a water sample without $\mathrm{DMSP}_{\mathrm{d}}$ amendment was incubated as a control.

Following the addition, the bottles were gently inverted. To avoid formation of headspace due to sampling and to ensure true independence of measurements, separate bottles were used for incubations representing time 0 , and 1,2 and $3 \mathrm{~h}$ of incubation. Sampling 4 times from the same bottle was compared with preparing 4 different bottles, but DMS concentrations did not show significant differences during the $3 \mathrm{~h}$ time period for either of the methods. Bottles were incubated in the dark and kept in a circulating waterbath during the time of incubation, with incubation temperatures being slightly higher (ca 0.5 to $1^{\circ} \mathrm{C}$ ) than the sampling depth temperatures (Table 1).

At each point in time, $60 \mathrm{ml}$ of water were filtered by low vacuum (never exceeding $12.7 \mathrm{~cm} \mathrm{Hg}$ ) using a Whatman GF/F glass fiber filter. In order to obtain a $1 \mathrm{~h}$ sampling frequency for each treatment, 1 sample had to be taken every $8 \mathrm{~min}$ and immediately processed for 


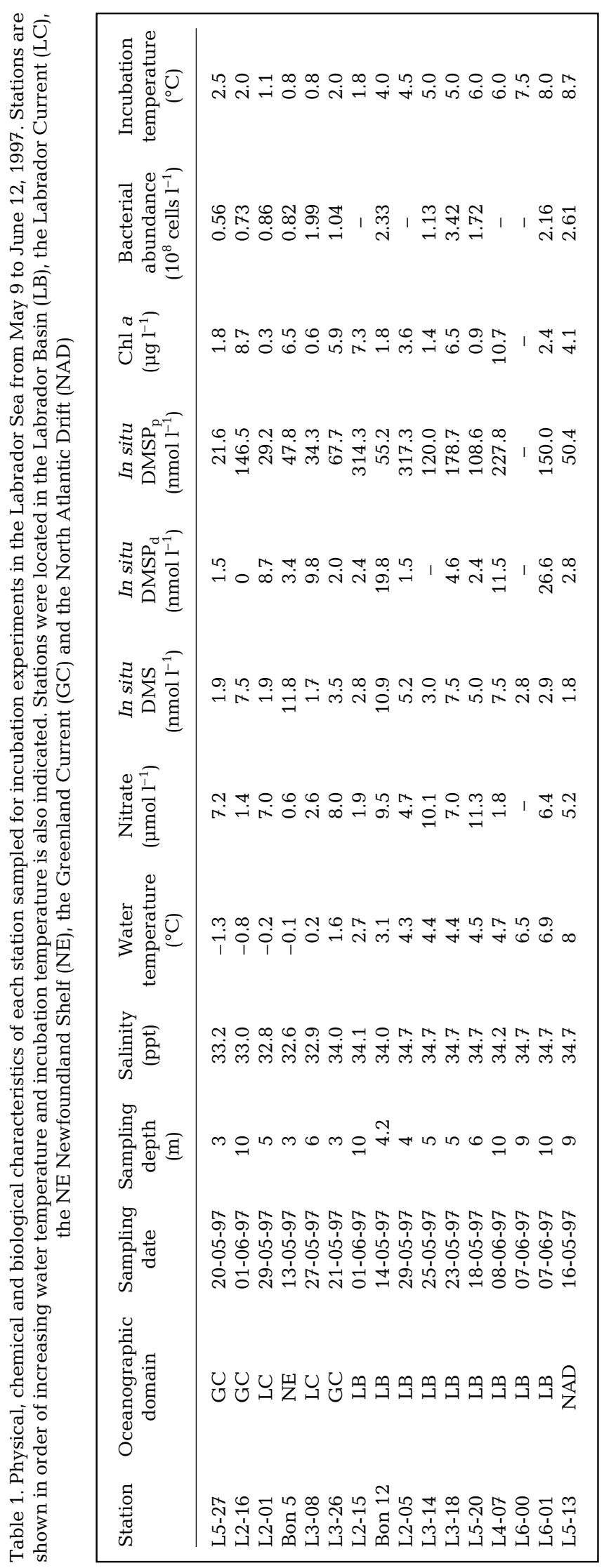

DMS and DMSP analysis. Due to this time constraint of the incubation protocol the filtration could not be done by gravity and no replication of the $\mathrm{DMSP}_{d}$ treatments was possible.

Sample analysis. For chromatographic analysis of DMS (<10 min after the end of the incubation), $23 \mathrm{ml}$ filtrate $+1 \mathrm{ml} \mathrm{H}_{2} \mathrm{O}$ were transferred into a $25 \mathrm{ml}$ serum bottle, closed with a grey butyl septum, crimp sealed and immediately measured. Laboratory tests have confirmed that there is no significant adsorption of DMS by butyl septa (Scarratt pers. comm.). For the determination of $\mathrm{DMSP}_{\mathrm{d}}, \mathrm{DMSP}_{\mathrm{d}}$ was hydrolyzed to DMS by addition of $1 \mathrm{ml} 10 \mathrm{~N} \mathrm{KOH}$ to $23 \mathrm{ml}$ of filtrate and allowed to react for a minimum of $24 \mathrm{~h}$ in the dark at $4^{\circ} \mathrm{C}$. In some cases, particulate DMSP (DMSP $)$ was also determined by suspending the glass fiber filters in $23 \mathrm{ml} \mathrm{H} \mathrm{H}_{2} \mathrm{O}$ and $1 \mathrm{ml} 10 \mathrm{~N} \mathrm{KOH}$. All DMSP samples (dissolved and particulate) were analyzed within $3 \mathrm{wk}$. Experiments conducted in our laboratory have shown that DMSP samples may be stored for this period of time without significant variation. The strong alkali treatment decomposes DMSP quantitatively and stoichiometrically to DMS and acrylate (Dacey \& Blough 1987). The measured quantity of DMS in filtered samples following $\mathrm{KOH}$ addition thereby represented the total amount of dissolved DMSP and free DMS. DMSP ${ }_{d}$ was computed as the difference between DMSP $_{d}+$ DMS and DMS. DMSP primary standards were prepared by carefully adding a weighed amount of DMSP-HCl (Research Plus Inc.) to $0.22 \mu \mathrm{m}$ filtered autoclaved natural seawater. The DMS and DMSP samples were measured on a Varian 3400 gas chromatograph (GC) equipped with a flame photometric detector (FPD) and a Chromosil 330 Teflon column (length $2.4 \mathrm{~m}$, packing length $1.8 \mathrm{~m}$, Supelco, Inc.) following a modified version of the method described by Leck \& Bågander (1988). Subsamples of up to $15 \mathrm{ml}$ were sparged with Helium at $40 \mathrm{ml} \mathrm{min}^{-1}$ in a $70^{\circ} \mathrm{C}$ heated bubble chamber for $5 \mathrm{~min}$. A Pyrex U-tube (30 cm long, $10 \mathrm{~mm}$ o.d.) immersed in a $60 \%$ $\mathrm{v} / \mathrm{v}$ isopropanol/water ice bath at $-32^{\circ} \mathrm{C}$ was used to remove most of the water vapor from the gas stream without condensation of DMS (Andreae 1980). Thereafter, a Teflon loop submerged in liquid nitrogen cryotrapped the DMS. The Teflon loop was subsequently heated $\left(\mathrm{ca} 70^{\circ} \mathrm{C}\right)$, releasing the extracted gas onto the GC column. The detection limit for DMS and $\mathrm{DMSP}_{\mathrm{d}}$ was $0.4 \mathrm{nmol} \mathrm{l^{-1 }}$, for $\mathrm{DMSP}_{\mathrm{p}}$ $0.16 \mathrm{nmol} \mathrm{l}^{-1}$.

Estimation of production rates. DMS production rates were estimated from the slope of the linear regression of the DMS timecourse. Regressions were based on at least 3 points in time.

Path analysis. In order to establish causal relationships between the measured DMS production rate 
following a $500 \mathrm{nmol} \mathrm{DMSP}_{\mathrm{d}} \mathrm{l}^{-1}$ addition, in situ water temperature and chl a concentrations, a path analysis (Sokal \& Rohlf 1981) was performed. Path analysis is an extension of multiple linear regression where the hypothesis as to causal relations among variables can be assessed (Sokal \& Rohlf 1981, Legendre \& Legendre 1984). To do so, linear equations are established that specify the causal order among variables. The equations for the model presented in Fig. 7 are:

$$
\text { chl } a=p_{11} \text { temperature }
$$

DMS production rate $=p_{21}$ temperature $+p_{22} \mathrm{chl} a$

The path coefficients $p$ between the different variables are then estimated by multiple regressions on standardized variables with the $\mathrm{R}$ package for multivariate data analysis of Legendre \& Vaudor (1991). Path coefficients are interpreted with emphasis on their signs and relative magnitudes, rather than their individual statistical significance (Sokal \& Rohlf 1981).

\section{RESULTS}

Table 1 presents the oceanographic domain, the sampling date and depth, salinity, water temperature, in situ concentrations of nitrate, chl $a$, DMS, dissolved and particulate DMSP, bacterial abundance and the incubation temperature for all stations sampled for incubations during NODEM 1. A detailed description of the sampling area, together with results for DMS, DMSP profiles and general oceanographic data collected during the cruise, will be published elsewhere (Cantin et al. unpubl.). Note that the in situ concentrations of nitrate, chl a, DMS, dissolved DMSP and particulate DMSP presented in Table 1 were determined by Cantin et al. (unpubl.).

In situ DMSP/DMS dynamics. In 14 out of 16 incubations, DMS concentrations in the unamended control bottles (in situ DMSP $_{d}$ concentrations) remained stable during the period of incubation. At Stns L3-14 and L3-18 in the Labrador Basin, linear net DMS production was observed at a rate of $1.94 \pm 0.27$ and $2.09 \pm 0.45 \mathrm{nmol} \mathrm{DMS} \mathrm{l}^{-1} \mathrm{~h}^{-1}$, respectively (Fig. 2). Net DMSP $_{\mathrm{d}}$ consumption at Stn L3-18 was also linear with respect to time (zero order kinetics) having a rate of $3.48 \pm 0.16$ nmol DMSP $\mathrm{l}^{-1} \mathrm{~h}^{-1}$. Stn L3-14 showed a similar initial $\mathrm{DMSP}_{\mathrm{d}}$ consumption rate, however it was not linear over $3 \mathrm{~h}$. At Stn L3-18, the maximum yield of DMS production from $\mathrm{DMSP}_{\mathrm{d}}$ was $60 \%$, calculated from net $\mathrm{DMSP}_{\mathrm{d}}$ consumption and net DMS production. At both stations the in situ $\mathrm{DMSP}_{\mathrm{d}}$ concentration measured in the control bottle at time 0 was $14 \mathrm{nmol} \mathrm{l}^{-1}$, resulting in an average turnover time of DMSP $_{\mathrm{d}}$ of $7 \mathrm{~h}$ (i.e. in situ DMSP $\mathrm{d}_{\mathrm{d}}$ net DMS production

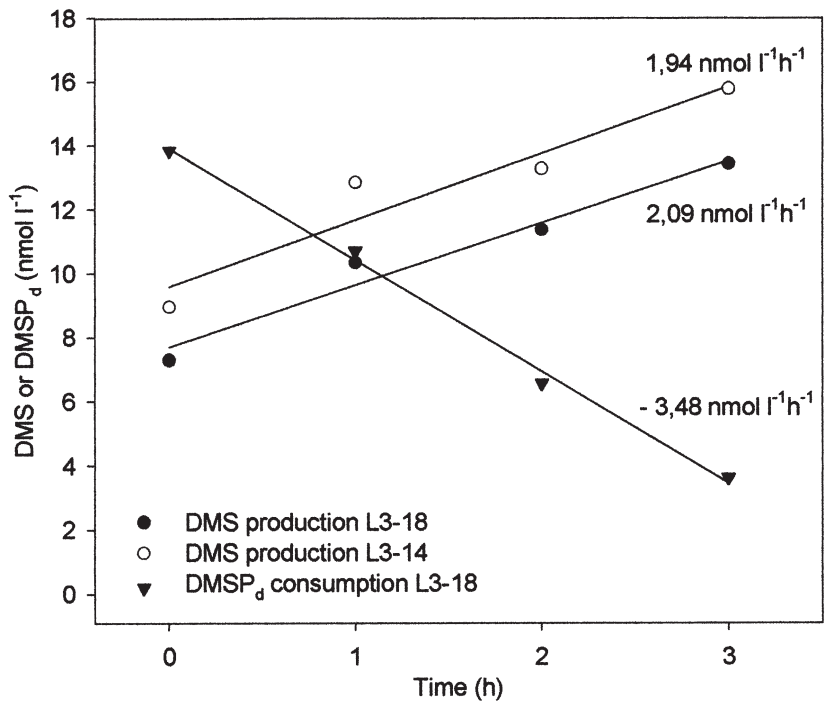

Fig. 2. Net DMS production and net $\mathrm{DMSP}_{\mathrm{d}}$ consumption observed in control bottles at Stns L3-14 and L3-18. The linear regression between DMS concentration and incubation time is indicated for each sample. Conversion efficiency of $\mathrm{DMSP}_{\mathrm{d}}$ to DMS at Stn L3-18 is $60 \%$

rate) with respect to $\mathrm{DMSP}_{d}$ cleavage. At Stn L3-18, the turnover time of $\mathrm{DMSP}_{\mathrm{d}}$ with respect to $\mathrm{DMSP}_{\mathrm{d}}$ net consumption was $4 \mathrm{~h}$ (i.e. in situ $\mathrm{DMSP}_{\mathrm{d}} /$ net $\mathrm{DMSP}_{\mathrm{d}}$ consumption rate).

DMS production kinetics from $\mathbf{D M S P}_{\mathrm{d}}$. Following DMSP $_{d}$ additions to water samples, 2 different response patterns were exhibited with respect to net DMS production, linear and non-linear. The linear response was generally observed at stations located in the Labrador Basin (Bon 12, L5-20, L3-14, L3-18, L2-05, L2-15, L6-00, L6-01 and L4-07), but also at stations over the NE Newfoundland Shelf (Bon 5), in the North Atlantic Drift (L5-13) and the West Greenland Current (L2-16). The non-linear response was observed at stations positioned in polar waters flowing along the Greenland and Labrador shelves, notably the Labrador Current (L2-01 and L3-08) and the West Greenland Current (L5-27 and L3-26) (Fig. 1). The 2 groups of stations are distinguished hereafter as group A (linear) and group B (non-linear).

Linear net DMS production in response to additions of DMSP $_{\mathbf{d}}$. At stations of group A (75\% of the stations sampled), net DMS production occurred immediately and at a linear rate during the incubation (see Fig. 3 for an example). However, to achieve a statistically significant linear rate $(\mathrm{p}<0.05, \mathrm{n}=4)$, additions of at least 100 nmol DMSP $\mathrm{D}_{\mathrm{d}}^{-1}$ were necessary. When several different $\mathrm{DMSP}_{\mathrm{d}}$ concentrations were added, the net DMS production rate increased proportionally with the substrate $\left(\mathrm{DMSP}_{\mathrm{d}}\right)$ concentration (see Fig. 4 for an example). No saturation in the rate of net DMS production was observed up to a concentration of 


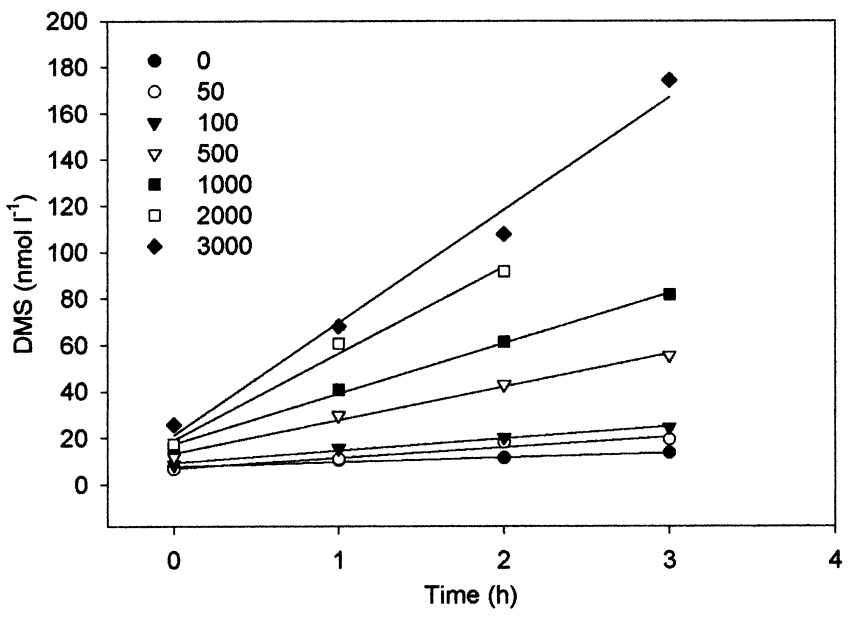

Fig. 3. Linear net DMS production response following additions of 0 to $3000 \mathrm{nmol} \mathrm{DMSP}_{\mathrm{d}} \mathrm{l}^{-1}$ (at Stn L3-18). The linear regression between DMS concentration and incubation time is indicated for each $\mathrm{DMSP}_{\mathrm{d}}$ addition

3000 nmol DMSP $\mathrm{D}^{-1}$ and on one occasion even up to $5000 \mathrm{nmol} \mathrm{DMSP} \mathrm{d}_{\mathrm{d}} \mathrm{l}^{-1}$ (Stn L5-13). Consequently, kinetic parameters $K_{\mathrm{m}}$, i.e. the affinity of the DMSPlyase to $\mathrm{DMSP}_{\mathrm{d}}$, and $V_{\text {max }}$ the maximum rate at which the DMSP-lyase can convert $\mathrm{DMSP}_{d}$ into DMS, could not be calculated.

The slopes of the linear regression between the net DMS production rate and the added $\mathrm{DMSP}_{\mathrm{d}}$ determined for 6 stations of group A (those stations with complete kinetics experiments) are shown in Table 2. These first order rate constants varied between 0.0081 and $0.0155 \mathrm{~h}^{-1}$. Based on the assumption that the

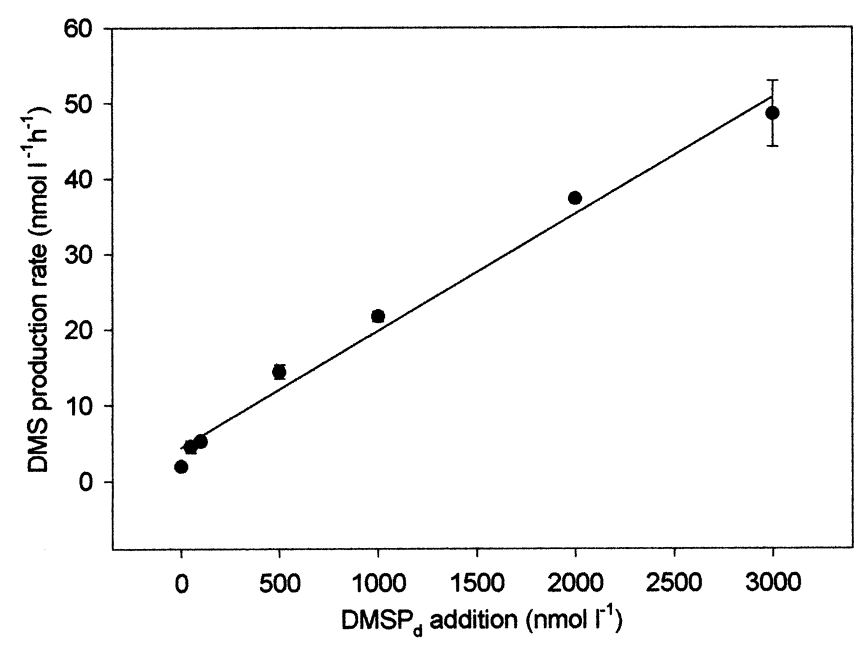

Fig. 4. Relationship between net DMS production rates and DMSP $_{d}$ additions for a sample collected at Stn L3-18. Error bars indicate the standard error (SE) calculated for the slope of the linear regressions between DMS concentration and incubation time for each $\mathrm{DMSP}_{\mathrm{d}}$ addition in Fig. 3 net DMS production rate remains constant over $24 \mathrm{~h}$, the rate constants allow an estimation of the percentage of the $\mathrm{DMSP}_{\mathrm{d}}$ pool that is cleaved to DMS $\mathrm{d}^{-1}$ (rate constant $\times 24 \times 100)$. In the study area, the average turnover time $\left(100 / \mathrm{DMSP}_{\mathrm{d}}\right.$ cleaved $\left.\mathrm{d}^{-1}\right)$ of the $\mathrm{DMSP}_{\mathrm{d}}$ pool, with respect only to cleavage to DMS, was $3.8 \mathrm{~d}$.

Non-linear net DMS production following DMSP $_{d}$ additions. Stations of group B (25\% of the stations sampled) showed a non-linear and overall low response in net DMS production for almost all $\mathrm{DMSP}_{\mathrm{d}}$ concentrations added. For low level additions of $\mathrm{DMSP}_{\mathrm{d}}\left(50\right.$ and $100 \mathrm{nmol} \mathrm{l} \mathrm{l}^{-1}$ ) the 2 stations in the Labrador Current (L2-01 and L3-08) showed no response in net DMS production. In the 1000 to $3000 \mathrm{nmol} \mathrm{DMSP} \mathrm{d}_{\mathrm{d}} \mathrm{l}^{-1}$ treatments, net DMS production at all 4 stations was low and characterized by a relatively strong increase after a lag of 1 or $2 \mathrm{~h}$ (see Fig. 5 for an example). Rates calculated for these $1 \mathrm{~h}$ production boosts ranged from 2.8 to $11.3,5.5$ to 19.6 and 5.2

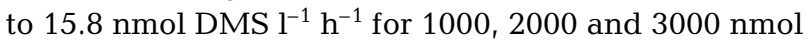
of added $\mathrm{DMSP}_{\mathrm{d}} \mathrm{l}^{-1}$, respectively.

Variation in potential net DMS production rates. The range of all significant linear net DMS production rates measured for the different $\mathrm{DMSP}_{\mathrm{d}}$ additions during NODEM 1 is listed in Table 3. All rates presented here are potential net DMS production rates following amendments with $\mathrm{DMSP}_{\mathrm{d}}$. When comparing the maximum rates between stations in groups $A$ and $B$, the few linear net DMS production rates measured in the Labrador and West Greenland currents (group B) are generally 3 to 10 times lower than those measured in the Labrador Basin, North Atlantic Drift and over the NE Newfoundland Shelf (group A). Moreover, the rates calculated for the $1 \mathrm{~h}$ production boosts in group $\mathrm{B}$ (see above) were also 2 to 3 times lower than the significant maximum rates measured for similar $\mathrm{DMSP}_{\mathrm{d}}$ treatments in group A.

Table 2. First order rate constants of net DMS production from $\mathrm{DMSP}_{\mathrm{d}}$ for stations with linear DMS production (group A). Rate constants are estimated from the slope of the linear regression between the net DMS production rate and the added $\operatorname{DMSP}_{\mathrm{d}}$. The percentage of $\mathrm{DMSP}_{\mathrm{d}}$ cleaved $\mathrm{d}^{-1}$ (rate constant $\times 24 \times 100$ ) and the turnover time of $\mathrm{DMSP}_{\mathrm{d}}$ by cleavage to DMS (100/percentage cleaved $\left.d^{-1}\right)$ are also presented

\begin{tabular}{|lccc|}
\hline Station & $\begin{array}{c}\text { Rate } \\
\text { constant } \\
\left(\mathrm{h}^{-1}\right)\end{array}$ & $\begin{array}{c}\text { DMSP }_{\mathrm{d}} \\
\text { cleaved d } \\
(\%)\end{array}$ & $\begin{array}{c}\text { DMSP }_{\mathrm{d}} \\
\text { turnover time } \\
(\mathrm{d})\end{array}$ \\
\hline Bon 5 & 0.0097 & 23.3 & 4.3 \\
Bon 12 & 0.0133 & 31.9 & 3.1 \\
L3-14 & 0.0088 & 21.1 & 4.7 \\
L3-18 & 0.0155 & 37.2 & 2.7 \\
L5-13 & 0.0147 & 35.3 & 2.8 \\
L5-20 & 0.0081 & 19.4 & 5.2 \\
\hline
\end{tabular}




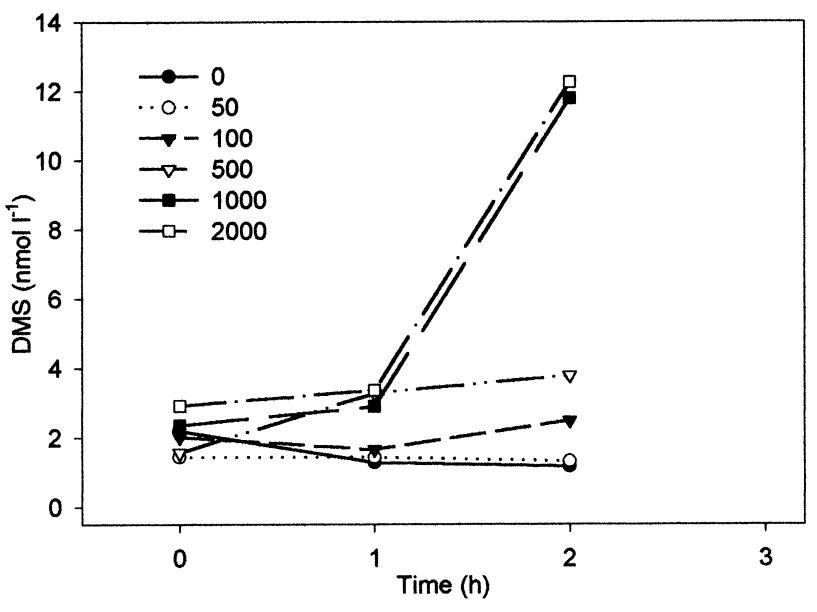

Fig. 5. Non-linear relation between DMS concentration and incubation time for additions of 0 to $2000 \mathrm{nmol} \mathrm{DMSP}_{\mathrm{d}} \mathrm{l}^{-1}$ and delayed net DMS production for a sample taken at Stn L2-01 as an example for stations of group B

For the same addition of $\mathrm{DMSP}_{\mathrm{d}}$, the resulting net DMS production rate determined throughout the study area varied by a factor of 4 to 11 . For example, following an addition of $500 \mathrm{nmol} \mathrm{DMSP}_{\mathrm{d}} \mathrm{l}^{-1}$, the rate determined at 14 different stations varied by a factor of 11 , from 1.7 to $18.4 \mathrm{nmol} \mathrm{DMS} \mathrm{l}^{-1} \mathrm{~h}^{-1}$ (Fig. 6). The variation of potential net DMS production rate was significantly correlated with changes in the in situ water temperature, chl a concentration, $\mathrm{DMSP}_{\mathrm{p}}$ concentration and bacterial abundance (Table 4). Bacterial abundance also displayed significant correlations with in situ water temperature, chl $a$ and $\operatorname{DMSP}_{\mathrm{p}}$.

\section{DISCUSSION}

\section{In situ DMSP/DMS dynamics}

During the oceanographic cruise NODEM 1 to the Labrador Sea in spring 1997, the microbial processes controlling the DMS concentrations in the surface

Table 3. Potential net DMS production rates following additions of 100 to $3000 \mathrm{nmol} \mathrm{DMSP}_{\mathrm{d}} \mathrm{l}^{-1}$ measured for stations of group A and group B in the Labrador Sea and North Atlantic. Minimum and maximum rates are presented when available

\begin{tabular}{|lcc|}
\hline $\begin{array}{l}\text { DMSP }_{\mathrm{d}} \text { addition } \\
\left(\mathrm{nmol} \mathrm{l}^{-1}\right)\end{array}$ & \multicolumn{2}{c|}{$\begin{array}{c}\text { Net DMS production rates } \\
\left(\mathrm{nmol} \mathrm{l}^{-1} \mathrm{~h}^{-1}\right)\end{array}$} \\
\hline 100 & Group A & Group B \\
\hline 500 & $1.4-5.3$ & 1.8 \\
1000 & $3.6-18.4$ & $1.7-2.2$ \\
2000 & $8.7-21.7$ & 2.2 \\
3000 & $8.1-37.3$ & 6.4 \\
& $25.2-48.5$ & 8.8 \\
\hline
\end{tabular}

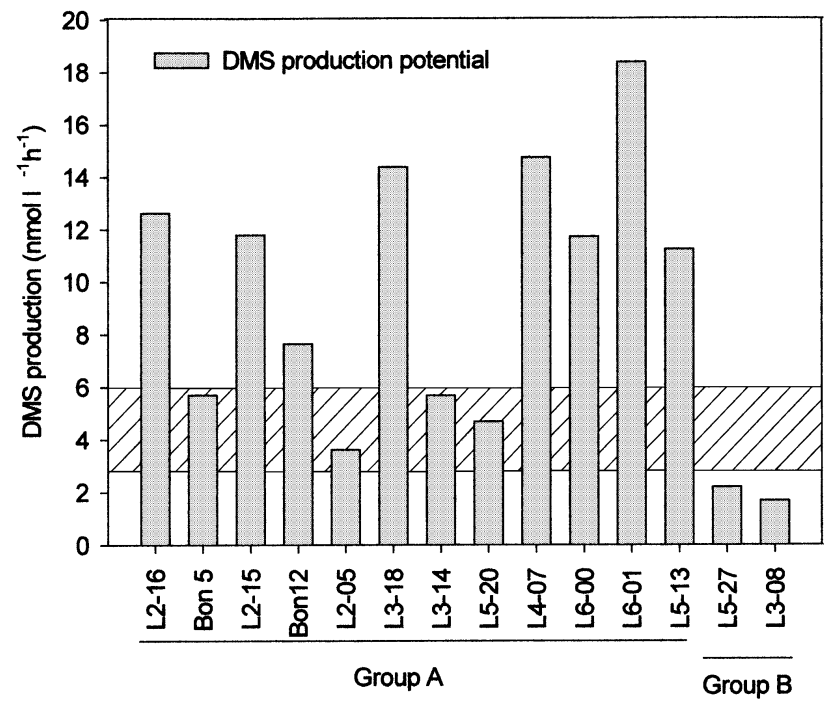

Fig. 6. Net DMS production rate measured at 14 stations in the Labrador Sea following an addition of $500 \mathrm{nmol} \mathrm{DMSP}$ $\mathrm{I}^{-1}$. The hatched area indicates the range of rates measured for the same $\mathrm{DMSP}_{\mathrm{d}}$ addition in temperate and warm oceanic and coastal waters (Ledyard 1993, Ledyard \& Dacey 1996a,b)

layer of the stations sampled seemed to be in an equilibrium state. DMS concentrations measured in the control bottles remained generally stable during the $3 \mathrm{~h}$ incubation, suggesting that DMS production and consumption by the microbial community were in balance. Departures from this equilibrium can occur and lead to significant build-up of DMS in the water and to degassing events to the atmosphere (Gibson et al. 1996 and references therein, Kwint \& Kramer 1996).

The linear net DMS production rates observed in the controls at Stns L3-14 and L3-18 (Fig. 2), both located in the central Labrador Sea, are examples where the balance between the processes had apparently been disturbed and shifted towards net DMS production. The net DMS production may have resulted from a higher gross DMS production and/or a lower DMS consumption. Gross DMS production at Stn L3-18

Table 4. Pearson correlation coefficients for net DMS production rates (Rate) following an addition of $500 \mathrm{nmol}$ $\operatorname{DMSP}_{\mathrm{d}} \mathrm{l}^{-1}$, bacterial abundance (Bacteria), in situ chl a (chl a) and particulate DMSP $\left(\mathrm{DMSP}_{\mathrm{p}}\right)$ concentrations measured during NODEM 1. No. of measurements (n) used in correlations are the maximum number possible for each pair of variables and varied between 9 and $16 .{ }^{*}$ Significant at $\mathrm{p} \leq 0.05$

\begin{tabular}{|llccc|}
\hline & Rate & Bacteria & Temperature & Chl $a$ \\
\hline Bacteria & $0.647^{*}$ & & & \\
Temperature & $0.506^{*}$ & $0.654^{*}$ & & \\
Chl $a$ & $0.581^{*}$ & $0.514^{*}$ & 0.117 & \\
DMSP $_{\mathrm{p}}$ & $0.645^{*}$ & $0.528^{*}$ & 0.368 & 0.401 \\
\hline
\end{tabular}


seemed indeed to be strong. $\mathrm{DMSP}_{\mathrm{d}}$ was consumed very rapidly, here at a rate of $3.48 \mathrm{nmol} \mathrm{l}^{-1} \mathrm{~h}^{-1}$, resulting in a turnover of only $4 \mathrm{~h}$. Assuming no $\mathrm{DMSP}_{d}$ was released from the particulate pool during the incubation, $60 \%$ of the degraded $\mathrm{DMSP}_{d}$ was converted to DMS, so DMS production from $\mathrm{DMSP}_{\mathrm{d}}$ probably dominated over competing pathways such as demethylation. Moreover, in situ DMS consumption at Stn L3-18 seemed to be of minor importance. Wolfe et al. (1999) measured very low DMS consumption at this station during the same cruise.

A stimulation of DMS production from DMSP ${ }_{d}$ could follow an enhanced release of DMSP from the particulate to the dissolved fraction due to the handling of the water sample or by a weakening of the light-deprived phytoplankton community during the incubation. Time 0 $\mathrm{DMSP}_{\mathrm{d}}$ levels in control bottles (data not shown) at $60 \%$ of the stations were 2 to 3.5 times higher than those in situ (Table 1), so DMSP ${ }_{d}$ must have been liberated by the manipulations between sampling and the first measurement. Hence, the observed net DMS production in the control may have been stimulated by artificial liberation of $\mathrm{DMSP}_{\mathrm{d}}$ at concentrations of about $10 \mathrm{nmol} \mathrm{l}^{-1}$. Why the surface water community responded to the small increase in $\mathrm{DMSP}_{\mathrm{d}}$ with net DMS production only at Stns L3-14 and L3-18 cannot be inferred from our data. However, the prevailing microbial community present in this part of the Labrador Sea seemed to be very sensitive to a shift towards a net DMS production mode and could rapidly turn over the $\mathrm{DMSP}_{\mathrm{d}}$. It seems that the equilibrium between DMS production and consumption processes can at times be very fragile.

\section{DMS production in response to $\mathrm{DMSP}_{\mathrm{d}}$ pulses: the linear response}

Amendment of the surface water samples with DMSP $_{d}$, which may simulate a sudden release of dissolved DMSP in the water at the end of an algal bloom, disturbs the equilibrium of DMS production and consumption processes. During this study, substrate addition always stimulated net DMS production, clearly indicating that DMS production throughout our study area was substrate limited. The incubation experiments conducted during our cruise generated 2 types of responses to the $\mathrm{DMSP}_{\mathrm{d}}$ addition: linear and nonlinear net DMS production.

Stations of group A were predominantly located in the Labrador Basin and displayed a linear response in net DMS production following $\mathrm{DMSP}_{\mathrm{d}}$ additions. At the time of sampling, the DMSP-lyase systems of the microbial community at stations of group A seemed to be well acclimatized to the in situ conditions and capa- ble of quickly utilizing $\operatorname{DMSP}_{\mathrm{d}}$. However, at most stations (except Stn L3-18) an addition of $100 \mathrm{nmol}$ DMSP $_{d} l^{-1}$ was necessary in order to obtain a statistically significant linear DMS production rate. Following $\mathrm{DMSP}_{\mathrm{d}}$ addition, the DMS production process was stimulated immediately and probably dominated over the concurrent DMS consumption. At several stations where kinetics experiments were conducted, Wolfe et al. (1999) measured DMS consumption by the inhibition with dimethyldisulfide (DMDS). DMS consumption rates at these stations (Bon 5, L5-20, L3-18 and L6-01) were only up to $2.3 \mathrm{nmol} \mathrm{DMS} \mathrm{l}^{-1} \mathrm{~h}^{-1}$. Moreover, at Stn L5-20, stimulation of DMS production by an

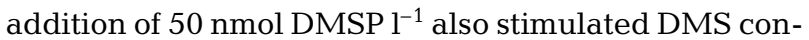
sumption, but DMS production stayed the dominant process (Wolfe et al. 1999).

The net DMS production rates measured following the $\mathrm{DMSP}_{\mathrm{d}}$ additions were proportional to substrate concentration, as previously reported by Kiene \& Service (1991), and followed first order kinetics. The kinetic parameters $K_{\mathrm{m}}$ and $V_{\max }$ could not be determined, due to a lack of saturation of net DMS production rates for $\mathrm{DMSP}_{\mathrm{d}}$ concentrations up to $5000 \mathrm{nmol} \mathrm{l}^{-1}$. The lack of saturation of the DMS production rate following such high $\mathrm{DMSP}_{\mathrm{d}}$ additions seems peculiar in light of in situ $\mathrm{DMSP}_{\mathrm{d}}$ concentrations that are typically in the tens of nmol $\mathrm{l}^{-1}$ and which ranged from 0 to $26.6 \mathrm{nmol} \mathrm{l}^{-1}$ in this study (Table 1). In a similar field study, however, Ledyard \& Dacey (1996b) found linear DMSP ${ }_{d}$ cleavage kinetics in seawater samples from the Sargasso Sea, with no signs of saturation for $\mathrm{DMSP}_{\mathrm{d}}$ amendments as high as $1000 \mathrm{nmol} \mathrm{l}^{-1}$. The same authors also reported extremely low affinity kinetics for DMS production from DMSP $_{d}$ in the temperate coastal waters in Monterey Bay (Ledyard \& Dacey 1996a) with apparent half saturation constants $\left(K_{\text {mapp }}\right)$ for $\mathrm{DMSP}_{\mathrm{d}}$ cleavage of 0.48 to $11.5 \mu \mathrm{mol} \mathrm{DMSP}_{\mathrm{d}} \mathrm{l}^{-1}$. Laboratory studies on the activity of bacterial DMSP-lyase have demonstrated $K_{\mathrm{m}}$ values ranging from several hundred nmol (Ledyard \& Dacey 1994) to $2 \mathrm{mmol}$ (De Souza \& Yoch $1995 a, b) \operatorname{DMSP}_{d} l^{-1}$. It seems that there is a large capacity for the microbial community, and especially bacteria, to use $\mathrm{DMSP}_{d}$ even at concentrations that far exceed those usually found in bulk seawater. It has been speculated that this could indicate an adaptation to ecological niches with high $\mathrm{DMSP}_{\mathrm{d}}$ concentrations (Ledyard \& Dacey 1994, de Souza \& Yoch 1995b). Such microenvironments with high dissolved organic carbon (DOC) concentrations are postulated to be associated with phytoplankton cells and in aggregates of marine snow (Mitchell et al. 1985). Recently, the determination of potential DMS production in size-fractionated seawater samples revealed that most of the activity was concentrated in the particulate fraction (Cantin et al. 1999). On the other hand, a study by Kiene et al. 
(1998) indicated a very high affinity for the uptake of DMSP by bacteria in the Gulf of Mexico with half saturation constants in the low nanomolar range. Scarratt et al. (in press) have shown that free-living bacteria may have higher $\mathrm{DMSP}_{\mathrm{d}}$ affinity than particle-associated bacteria. At one station (Bon 5) during this cruise, DMS production kinetics were determined following DMSP $_{\mathrm{d}}$ additions of 10, 20,50 and $100 \mathrm{nmol} \mathrm{l}^{-1}$. For the 10, 20 and 50 nmol DMSP $\mathrm{d}^{-1}$ treatments, net DMS production was low and non-linear with time (data not shown). It was not possible to resolve a saturation of DMS production at these near in situ DMSP $_{d}$ concentrations. The rapid and linear degradation of $\mathrm{DMSP}_{\mathrm{d}}$ in the control at Stn L3-18 however, could indicate a saturation of $\mathrm{DMSP}_{\mathrm{d}}$ uptake in the range of 14 to $4 \mathrm{nmol}$ $\mathrm{DMSP}_{\mathrm{d}} \mathrm{l}^{-1}$ (Fig. 2). This finding seems to contradict the apparent lack of saturation of net DMS production up to a concentration of $5000 \mathrm{nmol} \mathrm{DMSP} \mathrm{d}^{-1}$. However, it could point to multiphasic kinetics for $\mathrm{DMSP}_{\mathrm{d}}$ cleavage or to the presence of multiple enzyme systems that respond to different ambient concentrations of $\mathrm{DMSP}_{\mathrm{d}}$ either in the same organism or in several different organisms. Such a multiphasic uptake system has been proposed by Azam \& Hodson (1981) for the bacterial utilization of glucose that also displays bulk seawater concentrations near the level of detection. The authors measured uptake of glucose over a broad range of concentrations $\left(10^{-9}\right.$ to $\left.10^{-3} \mathrm{~mol} \mathrm{l}^{-1}\right)$ and found a gradual increase of the half saturation constant with increasing substrate concentration. The existence of a multiphasic uptake system for glucose has been shown for a bacterium isolated from oligotrophic seawater (Nissen et al. 1984). The isolate was able to take up glucose at concentrations varying from $10^{-9}$ to $10^{-3} \mathrm{~mol} \mathrm{l}^{-1}$. Several kinetic phases with increasing $K_{\mathrm{m}}$ and $V_{\max }$ values at increasing glucose concentrations could be resolved. Both studies speculate that the multiple phases observed are adaptations of the bacteria to considerable fluctuations of substrate concentrations that can occur in the marine pelagic environment. The data in this study do not provide direct evidence of the presence of multiphasic kinetics for DMS production from $\mathrm{DMSP}_{\mathrm{d}}$. However, it seems reasonable to assume that mechanisms similar to those for glucose uptake could govern the utilization of most sources of labile DOC, including $\mathrm{DMSP}_{\mathrm{d}}$. It remains to be verified whether multiphasic kinetics exist for DMSP and DMS cycling which could in part explain the large variability in kinetic parameters observed in previous studies as well as the lack of saturation found in this study.

The first order rate constants determined for 6 stations of group A do not vary considerably (Table 2). They give an estimate of the turnover time of the $\mathrm{DMSP}_{\mathrm{d}}$ pool present in the water at a given time. Throughout the Labrador Sea, an average of $28 \%$ of the $\mathrm{DMSP}_{\mathrm{d}}$ was degraded to DMS d $\mathrm{d}^{-1}$, i.e. the average turnover time was $3.8 \mathrm{~d}$. Since the rate constants were derived from net DMS production rates measured following several different $\mathrm{DMSP}_{\mathrm{d}}$ additions, they only take into account $\mathrm{DMSP}_{\mathrm{d}}$ cleavage to DMS. The turnover for $\mathrm{DMSP}_{\mathrm{d}}$ must therefore be seen as an upper limit.

\section{DMS production in response to $\mathrm{DMSP}_{\mathrm{d}}$ pulses: the non-linear response}

A non-linear response in net DMS production was observed at stations of group B. These stations are mostly located in the Labrador and West Greenland Currents. Seasonally covered with ice, surface water temperatures at these stations were consistently low (from -1.3 to $1.6^{\circ} \mathrm{C}$ ). Chl $a$ and $\mathrm{DMSP}_{\mathrm{p}}$ concentrations were also low whereas the nutrient levels were relatively high (2.6 to $8 \mu \mathrm{mol} \mathrm{l}^{-1}$ of nitrate), indicating that at the time of sampling the plankton community was in a pre-bloom or bloom condition. The microbial community responded to the additions of $\mathrm{DMSP}_{\mathrm{d}}$ only after a lag of 1 or $2 \mathrm{~h}$. The few significantly linear net DMS production rates measured for group B were all lower than those in group A. To achieve a similar maximum rate, approximately 3 to 10 times more substrate was required in group B than in group A (Table 3). The observed delay in DMS production and the greater demand for substrate in order to produce DMS could have been due to the lower temperatures or to the development stage of the microbial community. Several of our observations might be explained by what has been learned from studies on bacterial productivity, respiration, growth efficiency and substrate utilization in seasonally or permanently cold waters. Evidence for an enhanced substrate requirement to sustain active bacterial growth in the cold has been demonstrated repeatedly in the field and in the laboratory. During incubations examining the effect of substrate on the generation time of facultatively psychrophilic and mesophilic bacteria, Wiebe et al. (1992, 1993) found that at lower temperatures, a higher substrate concentration was required to maintain the same growth rate. In the seasonally ice-covered waters of the Arctic Ocean and in Resolute Passage (High Canadian Arctic), Pomeroy et al. (1990) observed active bacterial growth and substrate utilization only at substrate concentrations of dissolved amino acids with orders of magnitude above those measured in natural seawater. Similarly, the respiration of the microbial community during the spring bloom in Conception Bay, Newfoundland, at water temperatures below $3.5^{\circ} \mathrm{C}$ could only be stimulated by the addition of very high organic substrate concentrations (Pomeroy et al. 1991). The 
authors postulated that microbial metabolism and production in cold waters are limited by the ability of bacteria to transport and/or assimilate substrate at the usually low in situ concentrations. This decreasing affinity for substrate with decreasing temperature has been shown by Nedwell \& Rutter (1994) and, since most natural environments are substrate limited, they suggested that affinity is the most important factor in determining the outcome of competition between bacteria in the natural environment. However, Rivkin et al. (1996) argued that the average growth rate of bacterioplankton from cold and temperate seas appeared to be similar at their respective temperatures. Further work should explore the change in affinity for DOC of bacteria with DMSP-lyase and whether they would be more or less competitive at higher temperatures.

Low temperature also seems to affect the response time of bacteria to substrate enrichment. Kirchmann \& Rich (1997) found that bacteria incubated at colder temperatures respond more slowly to dissolved organic matter (DOM) additions than those incubated at higher temperatures. This observation is consistent with the lag in substantial net DMS production observed at the colder stations in the polar currents during this study (Fig. 5).

Nevertheless, immediate and linear net DMS production was sometimes found at very low temperatures during this study. This was the case at station Bon 5, where surface waters were influenced by the Labrador Current and had a temperature of only $-0.1^{\circ} \mathrm{C}$. The rapid and linear DMS production measured in the kinetics experiment at this station can be explained by the age of the bloom. Nitrate was almost depleted $\left(0.6 \mu \mathrm{mol} \mathrm{l}^{-1}\right)$ at this station and the bloom was in a more advanced stage. Probably, the DOC concentrations were higher and the bacterial community at Bon 5 was already very active. These findings are similar to results from a study on bacterial activity in a phytoplankton bloom in the Barents Sea (Thingstad \& Martinussen 1991). The authors suggested that changes in substrate availability during the different stages of the bloom are a more important factor in controlling bacterial activity than water temperature. It should be noted however, that the net DMS production rates measured at station Bon 5 were at the lower end of the range determined for stations of group A (Table 3), so low temperature still seems to limit DMSP cleavage by bacteria. Similarly, we also observed linear net DMS production at Stn L2-16 situated in the West Greenland Current with a water temperature of $-0.8^{\circ} \mathrm{C}$. The net DMS production rate measured at

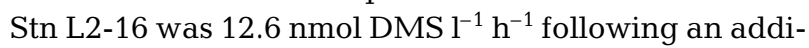
tion of $500 \mathrm{nmol}$ DMSP $_{\mathrm{d}} \mathrm{l}^{-1}$. This rate is ca 6 times higher than the rate measured at Stn L5-27 (see Fig. 6), also situated in the West Greenland Current. At all stations sampled in the West Greenland Current, the phytoplankton community was dominated by Phaeocystis pouchetii. Nitrate concentrations were 1.4 and $7.2 \mu \mathrm{mol} \mathrm{l}^{-1}$ and cell numbers of $P$. pouchetii were 3.02 and $0.59 \times 10^{6}$ cells $^{-1}$ for Stns L2-16 and L5-27, respectively. Unfortunately, water from Stn L5-27 was prescreened over $202 \mu \mathrm{m}$ before incubation so the cell count has to be interpreted with caution as some colonies might have been removed. Nevertheless, considering the northward movement of the water mass in the West Greenland Current and the relatively high values of nitrate at Stn L5-27 compared to Stn L2-16, one can still assume the bloom was aging towards the North. Therefore, the bloom at L2-16 seemed to be in a more advanced state than at Stn L5-27. The genus Phaeocystis sp. is a known strong producer of $\mathrm{DMSP}_{\mathrm{p}}$ and DMSP-lyase (Keller 1989, Stefels \& van Boekel 1993). The activity of the DMSP-lyase associated with Phaeocystis sp. cultures has been shown to decline with the age of the culture (Stefels \& van Boekel 1993). However, the activity of bacterial DMSP-lyase could become stronger towards the end of a bloom due to increased availability of substrate in the environment, as previously proposed by Kwint \& Kramer (1996). The natural bacterial community at Stn L2-16 was probably well preconditioned to DMSP utilization and could therefore cleave this substrate at a higher rate than at Stn L5-27. Despite the low temperature, the net DMS production rate measured at Stn L2-16 was of a similar magnitude than the rates measured at stations in warmer waters (see Fig. 6, Stns L3-18, L4-07 and L5-13 for example).

\section{Potential net DMS production rates in the Labrador Sea and other marine systems}

Potential net DMS production rates following an addition of $500 \mathrm{nmol} \mathrm{DMSP} \mathrm{d}_{\mathrm{d}} \mathrm{l}^{-1}$ determined during our study were at least comparable to, and sometimes higher than, those previously published for temperate and warm waters. Similar studies conducted in coastal and oceanic seawater reported net DMS production rates of 3 to $6 \mathrm{nmol} \mathrm{l}^{-1} \mathrm{~h}^{-1}$ for $\mathrm{DMSP}_{\mathrm{d}}$ additions of $500 \mathrm{nmol} \mathrm{l}^{-1}$ (Ledyard 1993, Ledyard \& Dacey 1996a,b). These rates, determined at water temperatures ranging from 7 to $25^{\circ} \mathrm{C}$ in the Sargasso Sea, Monterey Bay and Vineyard Sound, are often lower than the rates measured for the same $\mathrm{DMSP}_{\mathrm{d}}$ amendment in the Labrador Sea at water temperatures ranging from -1.3 to $8^{\circ} \mathrm{C}$ (see Fig. 6). Some of our rates are up to 3 times higher. On the other hand, in waters from a tidal creek amended with $500 \mathrm{nmol}$ DMSP $_{\mathrm{d}} \mathrm{l}^{-1}$ and incubated at $30^{\circ} \mathrm{C}$, Kiene (1990) observed initial DMS net production rates 1.2 to 2 times higher than those measured in 
the Labrador Sea, between 22 and $36 \mathrm{nmol} \mathrm{DMS} \mathrm{l}^{-1} \mathrm{~h}^{-1}$. Obviously, water temperature is not the only factor that determines the range of DMS net production rates measured in the Labrador Sea and in other marine environments.

\section{What controls the net DMS production potential of the Labrador Sea?}

Throughout our study area, the net DMS production rate observed following a substrate input into the system (i.e. the net DMS production potential) varied by over 1 order of magnitude. For example, the net DMS production rate measured following an addition of $500 \mathrm{nmol} \mathrm{DMSP} \mathrm{d}^{-1}$ varied by a factor of 11 between stations (Fig. 6). These rates were significantly correlated with in situ concentrations of chl a and particulate DMSP (DMSP $)_{\mathrm{p}}$, bacterial abundance and water temperature (Table 4).

By using path analysis, the cause and effect relationships between the different variables were investigated. The goal was to explain which variable(s) was responsible for the observed variation in net DMS production potential. Several models were created, taking into account the net DMS production potential, bacterial abundance, water temperature and either chl $a$ or $\mathrm{DMSP}_{\mathrm{p}}$ concentrations as an indicator of algal biomass. When solving the respective equations, the value of the path coefficient of net DMS production potential and bacterial abundance dropped sharply. This indicated that there was no direct link between the variables. This is not surprising since bacterial abundance is a poor indicator of bacterial activity in general (Meyer-Reil 1978) and DMS cycling in particular (Kwint et al. 1996). The simple correlation between the 2 variables was probably a spurious correlation, reflecting the combined influence of temperature on bacterial abundance and net DMS production. The path coefficient between bacterial abundance and temperature remained strong but bacterial abundance as a variable was subsequently suppressed from the model.

The model that explained most of the observed variation in DMS net production potential, at a level of significance of $\mathrm{p}<0.01$ ( $\mathrm{n}=13$ ), is shown in Fig. 7 . For the environmental variables measured during this study, water temperature and chl a concentration appeared to be responsible for $62 \%$ of the variation in the net DMS production potential between the different microbial communities. Non-causal covariation, which could have been due to variables not considered by the model, was negligible for the links between temperature and production potential (path coefficient $\left.p_{21}=0.54\right)$, and between chl $a$ and production potential $\left(p_{22}=0.62\right)$. The net DMS production potential in the study area increased with water temperature and the amount of algal biomass. Both variables were of similar but independent importance in controlling the potential rate. At higher temperatures, a system can show substantial net DMS production from $\mathrm{DMSP}_{\mathrm{d}}$ despite low chl a concentrations, as found at Stn L6-01. Low temperature seemed to limit the net DMS production potential. However, if the microbial community has been preconditioned to DMSP as a substrate, through the presence of Phaeocystis pouchetii in the water for instance, the temperature control on bacterial net DMS production loses its importance. This was apparently the case at Stn L2-16. Thus, the net DMS production potential in the different water masses of the study area was greater in warmer waters and in later stages of phytoplankton blooms dominated by DMSP-producing algal species.

For the overall regulation of marine DMS production, the CLAW hypothesis (Charlson et al. 1987) supposes a temperature control of algal biomass, especially for the subset of DMSP producers. According to our model for the Labrador Sea, surface water temperature and chl a do not show a direct causal relationship between each other. This was not surprising considering that the temperature control implied by Charlson et al. (1987) was a global assumption and included, for example, changes in oceanic circulation patterns and nutrient availability. When $\mathrm{DMSP}_{\mathrm{p}}$ was used as an indicator of algal biomass instead of chl $a$ in the model, less of the variation in net DMS production potential could be explained. DMSP $_{p}$ only takes into account a part of the phytoplankton community, unless it is dominated by DMSP producing species. However, metabolic activity of the microbial community, and specifically bacteria, is probably more strongly related to the overall phytoplankton biomass and all other labile forms of DOC, than to just $\mathrm{DMSP}_{\mathrm{d}}$. The observations in this study suggest that DMS production was mainly

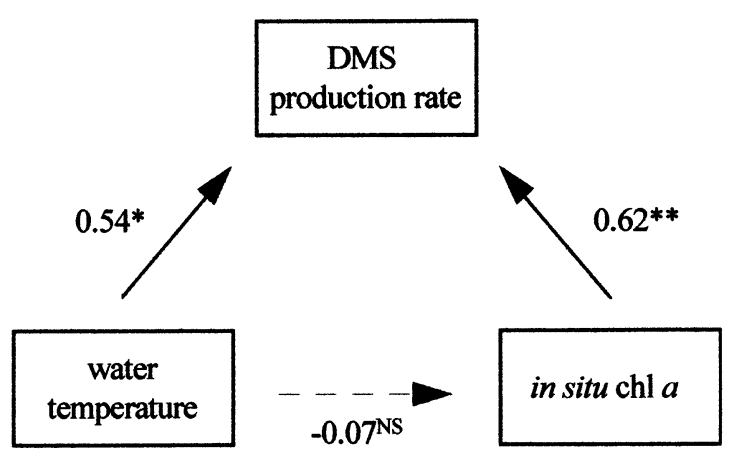

Fig. 7. Path diagram of possible causal relations (arrows) between in situ water temperature, in situ chl a concentration and the potential net rate of DMS production in the Labrador Sea in spring $\left({ }^{*} 0.01<\mathrm{p} \leq 0.05,{ }^{* *} \mathrm{p} \leq 0.01, \mathrm{NS}=\right.$ not significant $)$ 
mediated by bacteria. Regarding bacterial DMS production only, the results of the path analysis support the notion that a rise in water temperature enhances the marine DMS production potential. An effect of temperature on net DMS production following a pulse of $\mathrm{DMSP}_{\mathrm{d}}$ has been demonstrated previously by Kiene \& Service (1991). In situations where the bacterial component dominates the numerous food web processes implicated in DMSP and DMS cycling, DMS concentrations in the water could indeed be temperature regulated.

The residual variation (38\%) of the net DMS production potential in the model is probably due to variables not measured (Sokal \& Rohlf 1981), which could include general bacterial activity, bacterial conversion efficiency of DMSP $P_{d}$ to DMS and the amount of DMS produced from $\mathrm{DMSP}_{\mathrm{d}}$ by algal DMSP-lyase. In order to draw a more complete picture of what controls the net DMS production potential of a given water mass, future investigations in this area should include measurements of these parameters.

\section{CONCLUSIONS}

DMS production dynamics from $\mathrm{DMSP}_{\mathrm{d}}$ in the Labrador Sea seemed to be largely mediated by bacteria. DMS production was limited by the concentration of its substrate, $\mathrm{DMSP}_{\mathrm{d}}$, and by the water temperature, as has been proposed for the overall activity of bacteria in cold water environments (Pomeroy et al. 1991). Lower water temperatures generally required higher $\mathrm{DMSP}_{\mathrm{d}}$ concentrations to stimulate DMS production. Therefore, bacterial conversion of $\mathrm{DMSP}_{\mathrm{d}}$ to DMS seems to be governed by factors similar to those generally affecting bacterial substrate utilization. Variations in the net DMS production potential throughout the study area appear to be controlled by changes in water temperature, algal biomass in general, and the type and the age of the plankton community in particular. Compared to similar studies conducted in temperate and warm coastal and oceanic waters, the upper water column in the Labrador Sea shows an important potential for net DMS production. Potential net DMS production rates are up to 3 times higher in the Labrador Sea despite the lower temperatures. This finding reaffirms the importance of evaluating and modeling DMS fluxes from northern oceans. The data suggest a link between water temperature and net DMS production potential. Future work must verify this relationship for a greater range of temperatures above $8^{\circ} \mathrm{C}$ and in other oceanic systems before conclusions can be made about global, temperature-controlled, biological DMS production as a part of Charlson's climate feedback hypothesis.
Acknowledgements. The authors wish to thank the officers and crew of CCGS 'Hudson' during the NODEM 1 project, René-Christian Bouillon for assistance in the field, MarieLyne Dubé for nutrient analysis, Sylvie Lessard for the identification and enumeration of phytoplankton, Eric Tamigneaux, Esther Bonneau and Réal Gagnon for help and advice in the laboratory, Dr Gillian Malin and 2 anonymous reviewers for comments on earlier versions of this manuscript. The first author received post-graduate scholarships from the Fondation de l'Université du Québec à Rimouski and the Groupe de recherche en environnement côtier. This research was funded by the Maurice Lamontagne Institute (Department of Fisheries and Oceans, Canada) and by grants from the Natural Science and Engineering Research Council of Canada to M.L., M.G. and S.d.M. This is a contribution to the research program NODEM (Northern Oceans DMS Emissions Model) of the Ocean Climate Program of the Department of Fisheries and Oceans, Canada.

\section{LITERATURE CITED}

Andreae MO (1980) Determination of trace quantities of dimethylsulfoxide in aqueous solution. Anal Chem 52: 150-153

Andreae MO (1990) Ocean-atmosphere interactions in the global biogeochemical sulfur cycle. Mar Chem 30:1-29

Andreae MO, Crutzen PJ (1997) Atmospheric aerosols: biogeochemical sources and role in atmospheric chemistry. Science 276:1052-1058

Andreae MO, Elbert W, De Mora SJ (1995) Biogenic sulfur emissions over the tropical South Pacific: 3. Atmospheric dimethylsulfide, aerosols and cloud condensation nuclei. J Geophys Res 100(D6):11335-11356

Azam F, Hodson RE (1981) Multiphasic kinetics for D-glucose uptake by assemblages of natural marine bacteria. Mar Ecol Prog Ser 6:213-222

Bates TS, Charlson RJ, Gammon RH (1987) Evidence for the climatic role of marine biogenic sulfur. Nature 329: 319-321

Bates TS, Lamb BK, Guenther A, Dignon J, Stoiber RE (1992) Sulfur emissions to the atmosphere from natural sources. J Atmos Chem 14:325-337

Bates TS, Kiene RP, Wolfe GV, Matrai PA, Chavez FP, Buck KR, Blomquist BW, Cuhel RL (1994) The cycling of sulfur in surface seawater of the northeast Pacific. J Geophys Res 99(C4):7835-7843

Blunden G, Gordon SM (1986) Betaines and their sulphonio analogues in marine algae. Prog Phycol Res 4:39-80

Bratbak G, Levasseur M, Michaud S, Cantin G, Fernández E, Heimdal BR, Heldal M (1995) Viral activity in relation to Emiliania huxleyi blooms: a mechanism of DMSP release? Mar Ecol Prog Ser 128:133-142

Brimblecombe P, Shooter D (1986) Photo-oxidation of dimethylsulfide in aqueous solution. Mar Chem 19:343-353

Brussaard CPD, Riegman R, Noordeloos AAM, Cadée GC, Witte H, Kop AJ, Nieuwland G, van Duyl FC, Bak RPM (1995) Effects of grazing, sedimentation, and phytoplankton cell lysis on the structure of a coastal pelagic food web. Mar Ecol Prog Ser 123:259-271

Cantin G, Levasseur M, Gosselin M, Michaud S (1996) Role of zooplankton in the mesoscale distribution of surface dimethylsulfide concentrations in the Gulf of St. Lawrence, Canada. Mar Ecol Prog Ser 141:103-117

Cantin G, Levasseur M, Schultes S, Michaud S (1999) Dimethylsulfide (DMS) production by size-fractionated particles in the Labrador Sea. Aquat Microb Ecol 19:307-312 
Cantoni GL, Anderson DA (1956) Enzymatic cleavage of dimethylpropiothetin by Polysiphonia lanosa. J Biol Chem 222:171-177

Challenger F, Simpson MI (1948) Studies on biological methylation, Part 12, A precursor of the dimethyl sulphide evolved by Polysiphonia fastigata, Dimethyl-2-carboxyethylsulfonium hydroxide and its salts. J Chem Soc 3:1591-1597

Charlson RJ, Lovelock JE, Andreae MO, Warren SG (1987) Oceanic phytoplankton, atmospheric sulfur, cloud albedo and climate. Nature 326:655-661

Dacey JWH, Blough NV (1987) Hydroxide decomposition of dimethylsulfoniopropionate to form dimethylsulfide. Geophys Res Lett 14:1246-1249

Dacey JWH, Wakeham SG (1986) Oceanic dimethylsulfide: production during zooplankton grazing on phytoplankton. Science 233:1314-1316

De Mora SJ, Lee PA, Grout A, Schall C, Heumann KG (1996) Aspect of the biogeochemistry of sulphur in glacial melt water ponds on the McMurdo Ice Shelf, Antarctica. Antarct Sci 8:15-22

De Souza MP, Yoch DC (1995a) Purification and characterization of dimethylsulfoniopropionate lyase from an Alcaligenes-like dimethyl sulfide producing marine isolate. Appl Environ Microbiol 61:21-26

De Souza MP, Yoch DC (1995b) Comparative physiology of dimethyl sulfide production by dimethylsulfoniopropionate lyase in Pseudomonas doudoroffii and Alcaligenes sp. strain M3A. Appl Env Microbiol 61:3986-3991

Gibson JAE, Swadling KM, Burton HR (1996) Acrylate and dimethylsulfoniopropionate (DMSP) concentrations during and Antarctic phytoplankton bloom. In: Kiene RP, Visscher PT, Keller MD, Kirst GO (eds) Biological and environmental chemistry of DMSP and related sulfonium compounds. Plenum Press, New York, p 213-222

Hill RW, White BA, Cottrell MT, Dacey JWH (1998) Virusmediated total release of dimethylsulfoniopropionate from marine phytoplankton: a potential climate process. Aquat Microb Ecol 14:1-6

Holm-Hansen O, Lorenzen CJ, Holmes RN, Strickland JS (1965) Fluorometric determination of chlorophyll. J Cons Int Explor Mer 30:3-15

Jonkers HM, van der Maarel MJEC, van Gemerden $H_{\text {, }}$ Hansen TA (1996) Dimethylsulfoxide reduction by marine sulfate-reducing bacteria. FEMS Microb Lett 136:283-287

Keller MD, Bellows WK, Guillard RRL (1989) Dimethyl sulfide production in marine phytoplankton. In: Saltzman ES, Cooper WJ (eds) Biogenic sulfur in the marine environment. Symp Ser 393 American Chemical Society, Washington DC, p 167-182

Kiene RP (1990) Dimethyl sulfide production from dimethylsulfoniopropionate in coastal seawater samples and bacterial cultures. Appl Environ Microbiol 56:3292-3297

Kiene RP (1992) Dynamics of dimethyl sulfide and dimethylsulfoniopropionate in oceanic water samples. Mar Chem $37: 29-52$

Kiene RP (1996) Production of methanethiol from dimethylsulfoniopropionate in marine surface waters. Mar Chem 54:69-83

Kiene RP, Bates TS (1990) Biological removal of dimethyl sulphide from sea water. Nature 345:702-705

Kiene RP, Service SK (1991) Decomposition of dissolved DMSP and DMS in estuarine waters: dependence on temperature and substrate concentration. Mar Ecol Prog Ser 76:1-11

Kiene RP, Taylor BF (1988) Biotransformations of organosulfur compounds in sediments via 3-mercaptopropionate. Nature 332:148-150
Kiene RP, Hoffmann Williams LP, Walker JE (1998) Seawater microorganisms have a high affinity glycine betaine uptake system which also recognizes dimethylsulfoniopropionate. Aquat Microb Ecol 15:39-51

Kirchman DL, Rich JH (1997) Regulation of bacterial growth rates by dissolved organic carbon and temperature in the Equatorial Pacific Ocean. Microb Ecol 33:11-20

Kirst GO (1996) Osmotic adjustment in phytoplankton and macroalgae. In: Kiene RP, Visscher PT, Keller MD, Kirst GO (eds) Biological and environmental chemistry of DMSP and related sulfonium compounds. Plenum Press, New York, p 121-129

Kwint RLJ, Kramer KJM (1996) Annual cycle of the production and fate of DMS and DMSP in a marine coastal system. Mar Ecol Prog Ser 134:217-224

Kwint RLJ, Quist P, Hansen TA, Dijkhuizen L, Kramer KJM (1996) Turnover of dimethylsulfoniopropionate and dimethylsulfide in the marine environment: a mesocosm experiment. Mar Ecol Prog Ser 145:223-232

Laroche D, Vézina AF, Levasseur M, Gosselin M, Stefels J, Keller MD, Matrai PA, Kwint RLJ (1999) DMSP synthesis and exudation in phytoplankton: a modeling approach. Mar Ecol Prog Ser 180:37-49

Leck C, Bågander LE (1988) Determination of reduced sulfur compounds in aqueous solutions using gas chromatography flame photometric detection. Anal Chem 60:3353-3363

Leck C, Larsson U, Bågander LE, Johansson S, Hajdu S (1990) Dimethyl sulfide in the Baltic Sea: annual variability in relation to biological activity. J Geophys Res 95(C3): 3353-3363

Ledyard KM (1993) Marine microbial production of dimethylsulfide from dissolved dimethylsulfoniopropionate. Doctoral dissertation, WHOI-93-07, Woods Hole Oceanographic Institution

Ledyard KM, Dacey JWH (1994) Dimethylsulfide production from dimethylsulfoniopropionate by a marine bacterium. Mar Ecol Prog Ser 110:95-103

Ledyard KM, Dacey JWH (1996a) Kinetics of DMSP-lyase activity in coastal seawater. In: Kiene RP, Visscher PT, Keller MD, Kirst GO (eds) Biological and environmental chemistry of DMSP and related sulfonium compounds. Plenum Press, New York, p 325-335

Ledyard KM, Dacey JWH (1996b) Microbial cycling of DMSP and DMS in coastal and oligotrophic seawater. Limnol Oceanogr 41:33-40

Legendre L, Legendre P (1984) Écologie numérique, 2. La structure des données écologiques, 2nd edn. Presses de l'Université du Québec, Montréal

Legendre P, Vaudor A (1991) The R package for multivariate data analysis. Département des sciences biologiques, Université de Montréal

Levasseur M, Michaud S, Egge J, Cantin G, Nejstgaard JC, Sanders R, Fernandez E, Solberg PT, Heimdal B, Gosselin M (1996) Production of DMSP and DMS during a mesocosm study of an Emiliania huxleyi bloom: influence of bacteria and Calanus finmarchicus grazing. Mar Biol 126: 609-618

Liss PS, Hatton AD, Malin G, Nightingale PD, Turner SM (1997) Marine sulphur emissions. Philos Trans R Soc Lond 352:159-168

Lovelock JE, Maggs RJ, Rasmussen RA (1972) Atmospheric dimethyl sulfide and the natural sulfur cycle. Nature 237: $452-452$

Lund JWG, Kipling C, Le Cren ED (1958) The inverted microscope method of estimating algal numbers and the statistical basis of estimation by counting. Hydrobiologia 11: $143-178$ 
Malin G (1996) The role of DMSP and DMS in the global sulfur cycle and climate regulation. In: Kiene RP, Visscher PT, Keller MD, Kirst GO (eds) Biological and environmental chemistry of DMSP and related sulfonium compounds. Plenum Press, New York, p 177-198

Malin G, Kirst GO (1997) Algal production of dimethyl sulfide and its atmospheric role. J Phycologia 33:889-896

Malin G, Turner S, Liss PS, Holligan P, Harbour D (1993) Dimethylsulphide and dimethylsulfoniopropionate in the Northeast Atlantic during the summer coccolithophore bloom. Deep-Sea Res 40:1487-1508

Malin G, Liss PS, Turner SM (1994) Dimethyl sulfide: production and atmospheric consequences. In: Green JC, Leadbeater BSC (eds) The haptophyte algae. Systematics Association, Special Volume No. 51, Clarendon Press, New York, p 303-320

Malin G, Wilson WH, Bratbak G, Liss PS, Mann NH (1998) Elevated production of dimethylsulfide resulting from viral infection of cultures of Phaeocystis pouchetii. Limnol Oceanogr 43:1389-1393

Matrai PA, Keller MD (1993) Dimethylsulfide in a large-scale coccolithophore bloom in the Gulf of Maine. Cont Shelf Res 13:831-843

Matrai PA, Keller MD (1994) Total organic sulfur and dimethylsulfoniopropionate in marine phytoplankton: intracellular variations. Mar Biol 119:61-68

Meyer-Reil LA (1978) Autoradiography and epifluorescence microscopy combined for the determination of number and spectrum of actively metabolizing bacteria in natural waters. Appl Environ Microbiol 36:506-512

Mitchell JG, Okubo A, Fuhrman JA (1985) Microzones surrounding phytoplankton form the basis for a stratified marine microbial ecosystem. Nature 316:58-59

Nedwell DB, Rutter M (1994) Influence of temperature on growth rate and competition between two psychrotolerant Antarctic bacteria: low temperature diminishes affinity for substrate uptake. Appl Environ Microbiol 60:1984-1992

Nissen H, Nissen P, Azam F (1984) Multiphasic uptake of Dglucose by an oligotrophic marine bacterium. Mar Ecol Prog Ser 16:155-160

Pomeroy LR, Macko SA, Ostrom PH, Dunphy J (1990) The microbial food web in Arctic seawater: concentration of dissolved free amino acids and bacterial abundance and activity in the Arctic Ocean and in Resolute Passage. Mar Ecol Prog Ser 61:31-40

Pomeroy LR, Wiebe WJ, Deibel D, Thompson RJ, Rowe GT, Pakulski JD (1991) Bacterial responses to temperature and substrate concentration during the Newfoundland spring bloom. Mar Ecol Prog Ser 75:143-159

Porter KG, Feig YS (1980) The use of DAPI for identifying and counting aquatic microflora. Limnol Oceanogr 25:943-948

Rivkin RB, Anderson MR, Lajzerowicz C (1996) Microbial processes in cold oceans, I. Relationship between temperature and bacterial growth rate. Aquat Microb Ecol 10: 243-254

Scarratt M, Cantin G, Levasseur M, Michaud S (in press) Particle size-fractionated kinetics of DMS production: where does DMSP cleavage occur at the microscale? J Sea Res

Simó R, Grimalt JO, Pédrós l-Alió C, Albaigés J (1995) Occurrence and transformation of dissolved dimethyl sulfur species in stratified seawater (western Mediterranean Sea). Mar Ecol Prog Ser 127:291-299

Simó R, Hatton AD, Malin G, Liss PS (1999) Particulate dimethyl sulphoxide in seawater: production by microplankton. Mar Ecol Prog Ser 167:291-296

Sokal RR, Rohlf FJ (1981) Biometry: the principles and prac- tice of statistics in biological research, 2nd edn. Freeman and Co, San Francisco

Stefels J, Dijkhuizen L (1996) Characteristics of DMSP-lyase in Phaeocystis sp. (Prymnesiophyceae). Mar Ecol Prog Ser 131:307-313

Stefels J, van Boekel WHM (1993) Production of DMS from dissolved DMSP in axenic cultures of the marine phytoplankton species Phaeocystis sp. Mar Ecol Prog Ser 97:11-18

Steinke M, Wolfe GV, Kirst GO (1998) Partial characterization of dimethylsulfonio-propionate (DMSP) lyase isozymes in 6 strains of Emiliania huxleyi. Mar Ecol Prog Ser 889: 293-296

Strickland JDH, Parsons TR (1972) A practical handbook of seawater analysis, 2nd edn. Fish Res Board Can 167:1-310

Taylor BF, Gilchrist DC (1991) New routes of aerobic biodegradation of dimethylsulfoniopropionate. Appl Environ Microbiol 57:3581-3584

Taylor BF, Kiene RP (1989) Microbial metabolism of dimethyl sulfide. In: Saltzman ES, Cooper WJ (eds) Biogenic sulfur in the environment. Symp Ser 393 American Chemical Society, Washington DC, p 202-221

Taylor BF, Visscher PT (1996) Metabolic pathways involved in DMSP degradation. In: Kiene RP, Visscher PT, Keller MD, Kirst GO (eds) Biological and environmental chemistry of DMSP and related sulfonium compounds. Plenum Press, New York, p 265-276

Thingstad TF, Martinussen I (1991) Are bacteria active in the cold pelagic ecosystem of the Barents Sea? Polar Res 10: 255-266

Turner SM, Malin G, Liss PS, Harbour DS, Holligan PM (1988) The seasonal variations of dimethyl sulfide and dimethylsulfoniopropionate concentrations in nearshore waters. Limnol Oceanogr 33:364-375

Vairavamurthy A, Andreae MO, Iverson RL (1985) Biosynthesis of dimethylsulfide and dimethylpropiothetin by Hymenomonas carterae in relation to sulfur source and salinity variations. Limnol Oceanogr 30:59-70

Van Boekel WHM, Hansen FC, Riegman R, Bak RPM (1992) Lysis-induced decline of a Phaeocycstis spring bloom and coupling with the microbial foodweb. Mar Ecol Prog Ser 81:269-276

Velji MI, Albright LJ (1993) Improved sample preparation for enumeration of aggregated aquatic substrate bacteria. In: Kemp PF, Sherr BF, Sherr EB, Cole JJ (eds) Handbook of methods in aquatic microbial ecology. Lewis Publishers, Boca Raton, p 139-142

Wiebe WJ, Sheldon WM Jr, Pomeroy LR (1992) Bacterial growth in the cold: evidence for an enhanced substrate requirement. Appl Environ Microbiol 58:359-364

Wiebe WJ, Sheldon WM Jr, Pomeroy LR (1993) Evidence for an enhanced substrate requirement by marine mesophilic bacterial isolates at minimal growth temperatures. Microb Ecol 25:151-159

Wolfe GV, Bates TS (1993) Biological consumption of dimethyl sulfide in the marine euphotic zone: results of radioisotope experiments. In: Oremland RS (ed) Biogeochemistry of global change. Radiatively active trace gases. Chapman and Hall, New York, p 691-703

Wolfe GV, Levasseur M, Cantin G, Michaud S (1999) Microbial consumption and production of dimethylsulfide (DMS) in the Labrador Sea. Aquat Microb Ecol 18:197-205

Yentsch CS, Menzel DW (1963) A method for the determination of phytoplankton chlorophyll and phaeophytin by fluorescence. Deep-Sea Res 10:221-231

Zinder SH, Brock TD (1978) Dimethyl sulfoxide as an electron acceptor for anaerobic growth. Arch Microbiol 116:35-40 